\title{
Application of Web Discovery Services through VuFind
}

\author{
Sukumar Mandal \\ Assistant Professor, Department of Library and Information Science \\ The University of Burdwan, Burdwan - 713104
}

\begin{abstract}
Generally resource discovery services is available on Web environment. Discovery library service is a part of online searching tool for access the information resources both for local and global library users. Most of the libraries have been using the discovery services instead of online public access catalogue for wider access of metadata and full text. The essential features of discovery services including ranking algorithm, facets of different fields (authors, formats, main topics), Google like search box, enhanced search capability (fuzzy searching and concept searching), linking the full text content, customizing facilities for library, single window base interface for sign on the databases, integration with social sites, sharing the bibliographic information among the users. This paper discuss the application of discovery tools in integrated library management and retrieval system for the any type or size of a library. This is one of the important concept in automated and digital library system. This research paper select the matured level open source discovery tool for the import of Koha bibliographic data into the VuFind discovery tool and all the data can be easily access by the users as well as advanced users. VuFind support many open source library management software and it also support the digital library related software. The main outcome of this research paper are: (i) Bibliographic data of Koha display in VuFind, (ii) users can easily access the data and bibliographic information, (iii) Display of Emerald records of different items in VuFind, and (iv) Advanced level search facilities. All the tasks have been successfully implemented in Ubuntu 18.04 version and VuFind 4.1.1 version.
\end{abstract}

Keywords : Discovery services, VuFind discovery tool, Citation styles, Channel search, and Bibliographic information

\section{Introduction}

The vital function of a library and information centre is to fullfil the information needs of its users by cattering pinpointed, exhaustive and expeditious information repositories effectively and efficiently. Due to the advent of information communication technology libraries are facing a challenge how the enormous information content be provided very systematically so that the users can be best satisfied with close proximity with the relevant data of their needful literature. And this is the very discovery web service which enables a user with the huge amount of literature and their accessable data. This data service which was present earlier only confined to a particular library and information system. But now a days the situation has been radically changed where the users are getting a chance of introducing with the ocean of knowledge of information with the help of varities of web mechanism tools and techniques. This new web discovery service has changed the library environment, the protentiality of which offers a great extent of quickest and seamless integration of both regional and international web information resources rather a global repository. To achieve these web discovery services a systematic web management techniques is to be introduced and applied with the automated as well as digital library system. Information professionals of present digital era are utilizing discovery service tools in serving their users when enormous information 
DOI: https://dx.doi.org/10.26808/rs.ca.i8v1.09 International Journal of Computer Application (2250-1797) Issue 8 Volume 1, January- February 2018

content of digitized form would be easily accessed by them and, searching and retrieval of only printed form of literature has been transformed into the digital searching and retrieval technique. This is the beauty of the web discovery services as urgently invited by the libraries and information centre throughout the World.

\section{Scope and Features of Web Discovery Service}

This new service technique has revolutionary changed the environment of conventional library activities by offering a huge protential service of getting the enormous information digital repository to the users to a greater extent. It is greater improvement over the earlier indexing techniques and information delivery procedures and this procedures is equally adopting a digital harvesting process of searching multiple information repositories in varied form as well as in varied content which drastically changed the mannual procedure into logical and ontological information harvesting techniques into the World Digital Repositories (WDR) which is parallel to the universe of knowledge and information (UOI). Web scale discovery services have some important features viz., (i) information content (ii) discovery process to access the content (iii) efficient delivery procedure from multiple repositories, and (iv) the flexibility of all searching as well as managing procedure.

(i) The content is a huge collection of digital resources harvested both from local and global repositories available in the web environment and suitably indexed for better and easy serching where librarians, producers of information, brokers of informations are equally involved in creating comprehensive centralized index of content.

(ii) Discovery process to access the contents is nothing but the searching technique on a interface to find out this comprehensive digital content with the help of Google and any other relevant search engine which provide the information intermediaries to connect the users with the global information repositories.

(iii) Efficient delivery procedure from multiple repositories means an quickest supply of relevent set of data from various repositories by using the faceted navigation and federated searching.

(iv) Flexibility in web discovery service indicates any form of adoptive procedure to be applied at any point of time from content generation to discovery process and finally to web indexe delivery process for better management and control of web discovery services.

\section{Review of Related Works}

According to report commissioned by Research information Network, it is found (Research information Network, 2006). Fagan and others observed that both researchers and software developers in the field of Information Science opined user satisfaction is the ultimate indicators to be a successful information product. The same thing is true in the field in the field of Library and information science (Fagan \& others, 2012). Gross \& Sheridan reported that most of the users of academic library prefer Google and they generally use Google for their assignments (Gross \& Sheridan, 2011). The same study has been designed by Thompson, Obrig \& Abate and the same result was observed as per observations of Gross \& Sheridan (Thompson, Obrig \& Abate, 2013). Hoeppner evaluated the services of web scale discovery and stated that the discovery service deletes the information from the search and it can retrieve the full text. He also opined that Common Programming standards are regarded in the field of library science as "discovery layers" (Hoeppner, 2012). Hoy observed that the undergraduate students more and often like to spend 'the least possible time' while accessing information they need (Hoy, 2012). In the report of Loughborough 
DOI: https://dx.doi.org/10.26808/rs.ca.i8v1.09 International Journal of Computer Application (2250-1797) Issue 8 Volume 1, January- February 2018

University, the effect of library discovery technologies and libraries usage statistics report is found. It is also observed that in the report an evaluative study on the effect of the technologies of library discovery based on the users statistics of academic content (Loughborough University,2013). Mandal developed a domain specific cluster for college libraries affiliated to the University of Burdwan and he actually developed a framework which is basically developed for the academic libraries especially for college libraries (Mandal, 2017). Mandal and Trpathi discussed on e-book readers worked under the environment of Ubuntu and the study is based on the learners of Ubuntu(Mandal\& Tripathi, 2016). In a study Mandal discussed a comparative analysis on different software, standards and services and he also did this to set up an integrated library system (Mandal, 2016). Mandal observed the role of search indexing tools in the automation of libraries and gave a comparative study on different popular search indexing tools (Mandal, 2016). In a study by Mandal, it is found that MultiTes a tool may be used for the construction of Thesaurus and in this paper he also showed how a thesaurus can be constructed through the use of online tool effectively (Mandal, 2015). Shi and Sarah both used the term library discovery tools as web discovery tools and it is used at the time of mentioning search engines developed for the libraries. These tools are generally used for advanced searching and also for academic purpose. They analyzed various library discovery tools in the context of open search engines indexed in the Internet (Shi \& Sarah, 2015) . Thompson and others in a paper studied on Web-Scale Discovery in the Health Libraries as a special library and he also opined that Google is the best search engine and highly used by academic community to meet the demand of their needs (Thompson, Obrig \& Abate, 2013).

\section{Objectives}

The objectives of this paper are as follows :

(i) To explore the discovery services of Emerald database in VuFind.

(ii) To display the Koha bibliographic records in VuFind.

(iii) To search the multidesciplinary database by VuFind single window based interface.

(iv) To explore the advanced search facilities in VuFind discovery services.

\section{Discovery Interface of VuFind}

VuFind is an open source library search engine that allows users to search and browse beyond the resources of a traditional OPAC. Developed by Villanova University, version 1.0 was released in July 2010 after two years in beta. VuFind operates with a simple, Google-like interface and offers flexible keyword searching (Henry, 2015). While most commonly used for searching catalog records and it can be extended to search other library resources including but not limited to: locally cached journals, digital library items, and institutional repository and bibliography. It supports the multilingual interface in user as well as admin interface. Faceted search results that allow users to narrow items by format, call number, language, author, genre, era, region, and more. The Figure -1 represents the discovery interface of VuFind for browsing capability. Personal organization and annotation of resources through favorites lists, texting, e-mailing, tagging, and commenting features (VuFind, 2016). A patron centered library is extensible; it remains flexible and reactive to user needs. Technology is a tool, not an end, so librarians explore new technology in a climate where experimentation is encouraged through sound management techniques. 
DOI: https://dx.doi.org/10.26808/rs.ca.i8v1.09

International Journal of Computer Application (2250-1797)

Issue 8 Volume 1, January- February 2018

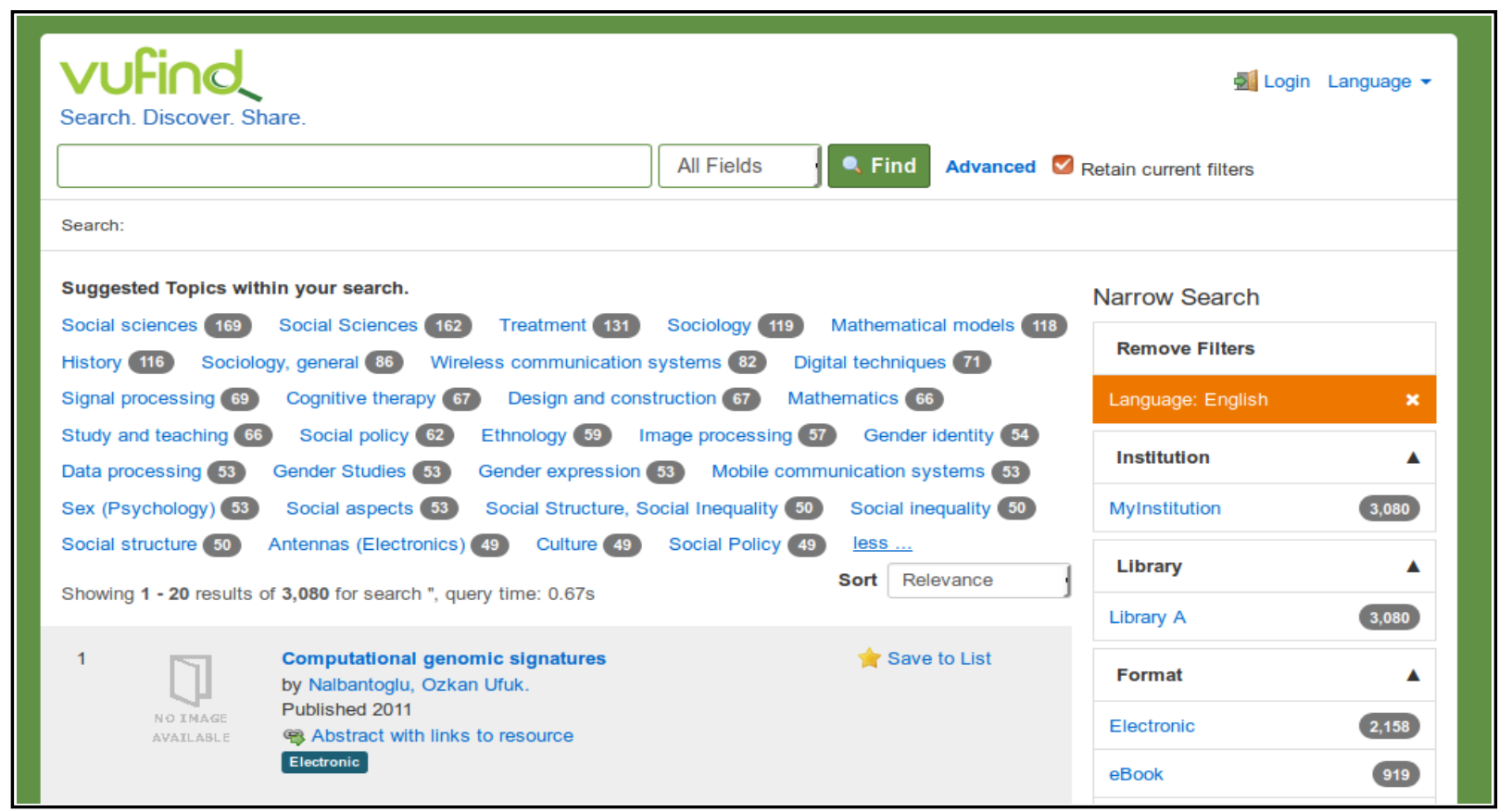

Figure -1 : Discovery interface of VuFind

The search system allows for the user to search from a basic search box and then to be able to narrow down the results by clicking on the various facets of the results. The user has the ability to save the resources from both the search results page and from the record view page to their own customizable lists. The lists can be retrieved at any time and will always be there for the user. This helps to eliminate the need for desktop based citation management software that tends to be too difficult for basic users and this makes it simple for all users. The Basic Search allows users to search for items by keyword, title, author, subject, or ISBN/ISSN. To conduct a Title Search, select Title from the dropdown menu. The Title Search allows users search for specific titles or for words found in the title. To conduct an Author Search, select Author from the dropdown menu. To search for a particular author, type the author's name (e.g. S.R. Ranganathan or Ranganathan, S.R.) into the search bar. Both search strategies will retrieve the same results. The Subject Search will allow users to do a keyword search of the subject field of each item of the catalog. It is also possible the ISBN or ISSN of the item user enter the ISBN/ISSN into the search bar, with or without dashes. The Advanced Search in VuFind allows users to conduct a more refined search. User can enter search terms in multiple fields using Boolean operators and limit by language or format and also find their relevant documents. The user has the ability to browse the catalog allowing them to explore what the library has rather than only being able to see a very narrow spectrum of results. VuFind has many APIs to interact with the search, data and many other features. It is designed to enable all library users to search and browse through all of the library's resources by replacing the traditional OPAC and it offers multiple search facilities such as faceted searching, suggested resources, personal organisation (eg favourites tagging or commenting features), and also offers versions in several languages including French, Chinese, Hebrew, Hindi and etc. The search results interface is represents in the Figure -2 . 
DOI: https://dx.doi.org/10.26808/rs.ca.i8v1.09

International Journal of Computer Application (2250-1797)

Issue 8 Volume 1, January- February 2018

\begin{tabular}{|c|c|c|c|c|}
\hline \multirow[t]{3}{*}{1} & \multirow{3}{*}{$\begin{array}{l}\text { NO TMAGE } \\
\text { AVATLABLE }\end{array}$} & \multirow{3}{*}{$\begin{array}{l}\text { Computational genomic signatures } \\
\text { by Nalbantoglu, Ozkan Ufuk. } \\
\text { Published } 2011 \\
\text { Abstract with links to resource } \\
\text { Electronic }\end{array}$} & \multirow[t]{3}{*}{ Save to List } & Format \\
\hline & & & & Electronic \\
\hline & & & & eBook \\
\hline \multirow[t]{4}{*}{2} & \multirow{4}{*}{$\prod_{\substack{\text { NO IMAGE } \\
\text { AYAILABLE }}}$} & \multirow{4}{*}{$\begin{array}{l}\text { Pragmatic electrical engineering systems and instruments / } \\
\text { by Eccles, William J. } \\
\text { Published } 2011 \\
\text { Abstract with links to resource } \\
\text { Electronic }\end{array}$} & \multirow{4}{*}{ Save to List } & Book \\
\hline & & & & Call Number \\
\hline & & & & T - Technology \\
\hline & & & & Q-Science \\
\hline \multirow[t]{3}{*}{3} & \multirow{3}{*}{$\prod_{\substack{\text { NO IMAGE } \\
\text { AVATLABLE }}}$} & \multirow{3}{*}{$\begin{array}{l}\text { Sustainable innovation a guide to harvesting the untapped } \\
\text { riches of opposition, unlikely combinations, and a plan B / } \\
\text { by Borbye, Lisbeth. } \\
\text { Published } 2011 \\
\text { Abstract with links to resource } \\
\text { Electronic }\end{array}$} & \multirow[t]{3}{*}{ Save to List } & R - Medicine \\
\hline & & & & $\mathrm{H}$ - Social Science \\
\hline & & & & $\begin{array}{l}\text { B - Philosophy, Psychology, } \\
\text { Religion }\end{array}$ \\
\hline \multirow[t]{3}{*}{4} & \multirow{3}{*}{$\begin{array}{l}\text { NO IMAAGE } \\
\text { AVAILABLE }\end{array}$} & \multirow{3}{*}{$\begin{array}{l}\text { Control system synthesis a factorization approach. } \\
\text { by Vidyasagar, M. 1947- } \\
\text { Published } 2011 \\
\text { Abstract with links to resource } \\
\text { Electronic }\end{array}$} & \multirow[t]{3}{*}{ Save to List } & $\begin{array}{l}\text { G - Geography, Anthropology, } \\
\text { Recreation }\end{array}$ \\
\hline & & & & more ... \\
\hline & & & & Author \\
\hline \multirow[t]{2}{*}{5} & & \multirow{2}{*}{$\begin{array}{l}\text { Control system synthesis a factorization approach. } \\
\text { by Vidyasagar, M. 1947- }\end{array}$} & \multirow{2}{*}{ Save to List } & SpringerLink (Online service) 221 \\
\hline & & & & Society of Photo-optical \\
\hline
\end{tabular}

Figure -2 : Search results of VuFind

\section{Emerald Search Results}

It is also known as single window based interface in discovery services. This interface is very attractive and interesting to users for access the relevant information with fulltext those are available in Emerald database relating the multidesciplinary aspects like Books, Journals, Conference procedings and etc.

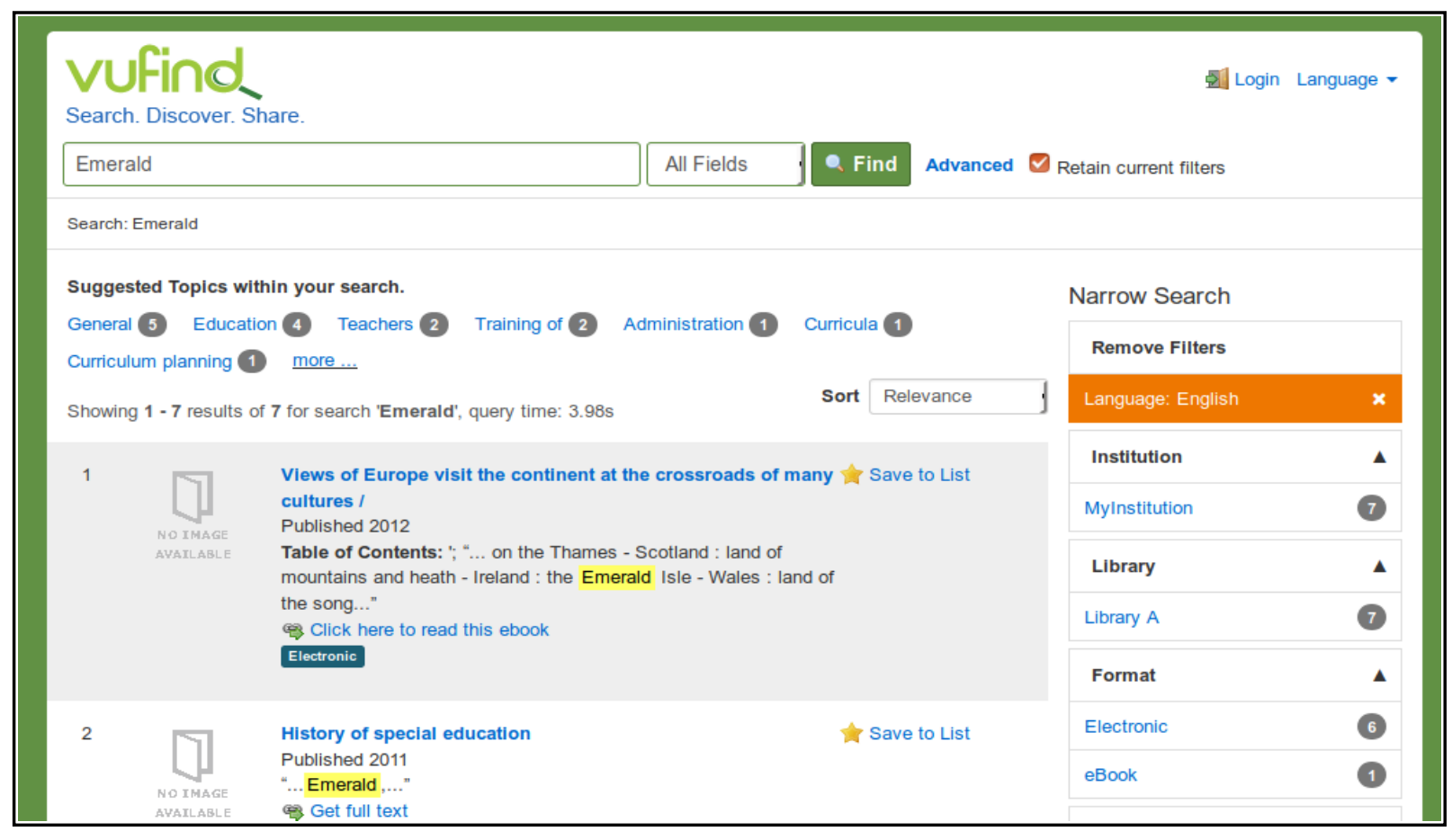

Figure -3 : Emerald search results of VuFind 
DOI: https://dx.doi.org/10.26808/rs.ca.i8v1.09 International Journal of Computer Application (2250-1797) Issue 8 Volume 1, January- February 2018

\section{Reference Management Interface in VuFind}

Citation styles can be found by using the VuFind discovery interface supports the three citation styles like APA, MLA and Chicago. The researcher and research scholar can easily managed their citation for bibliographic citation is a reference to a book, article, web page, or other published item. Citations should supply detail to identify the item uniquely. Different citation systems and styles are used in scientific citation, legal citation, prior art, and the arts and the humanities. Different citation styles is represent in the Figure -4 for the better management of research work of a particular topic.

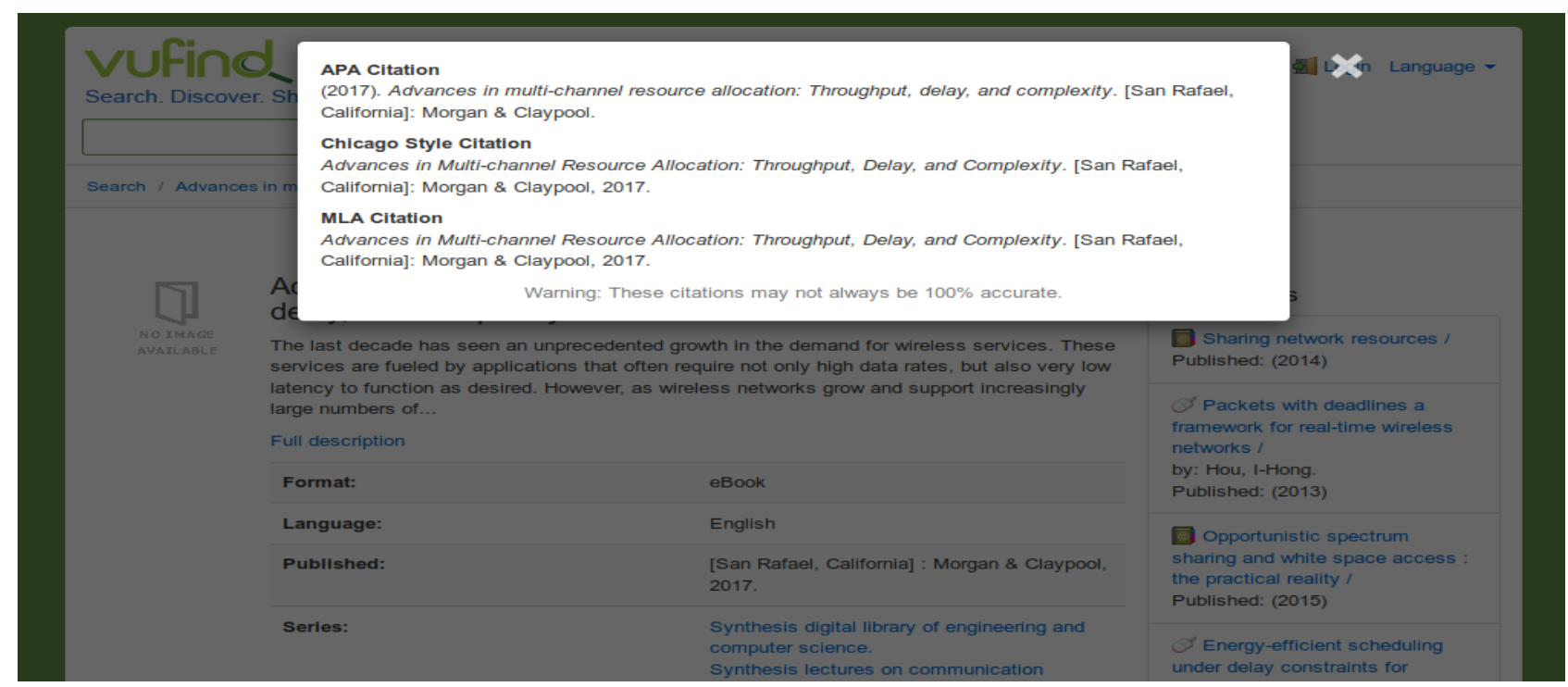

Figure -4 : Reference management styles of VuFind

\section{Koha Bibliographic data display in VuFind}

VuFind discovery tool is high performance indexing data because its fully support the Solr indexing. Bibliographic data is also an important things in discovery services. This section has successfully import the multiple bibliographic records of Koha into the VuFind single window based interface. Any users can search and see the suitable results of different fields like author, title, subject and etc. for the better and efficient management of library functions and activities. Obviously, it can saved the time of the reader.

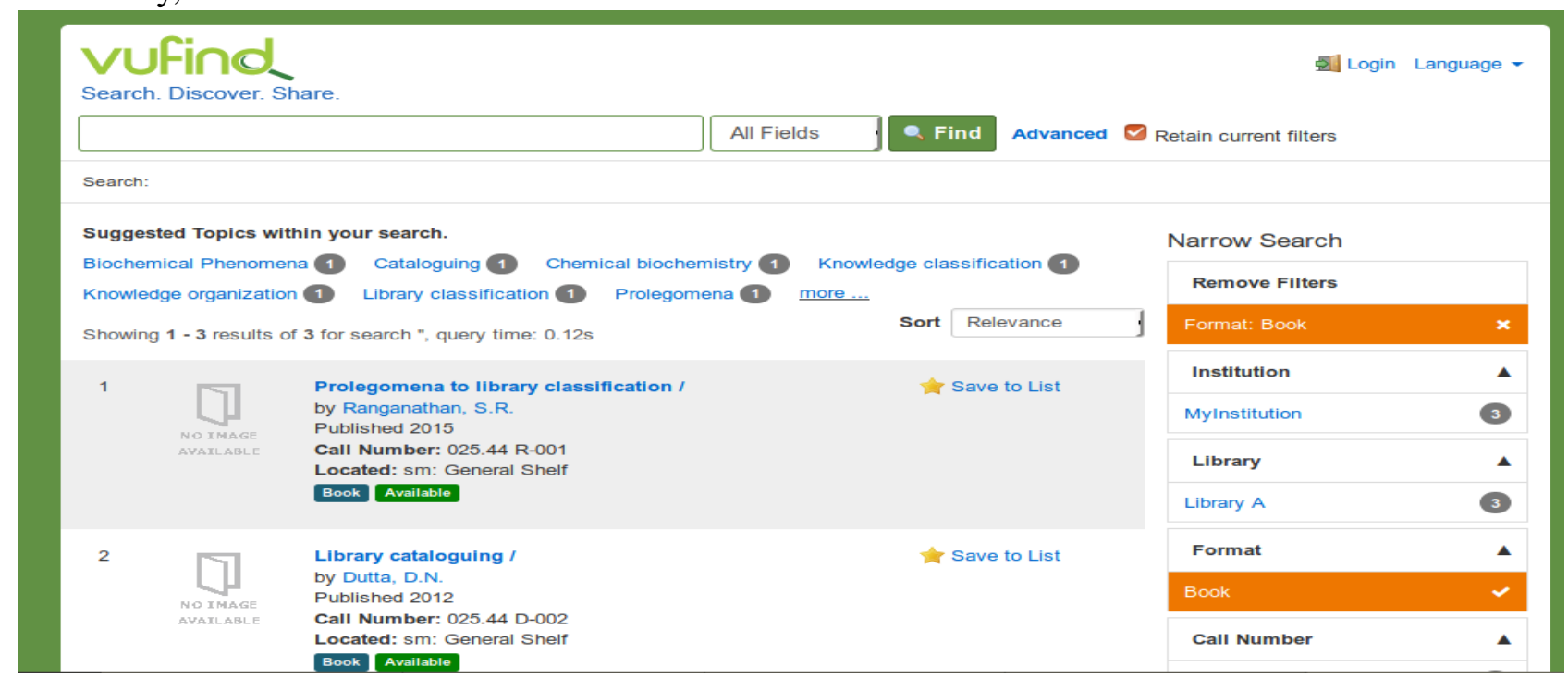

Figure -5 : Koha bibliographic data display in VuFind 


\section{Channel Search Interface in VuFind}

This is the new discovery service in VuFind. Channel search facility is only provide by the VuFind. It can be devided in two ways such as explore related channels and view records. Cross searching is also possible only by click on title of a particular item which available in VuFind.

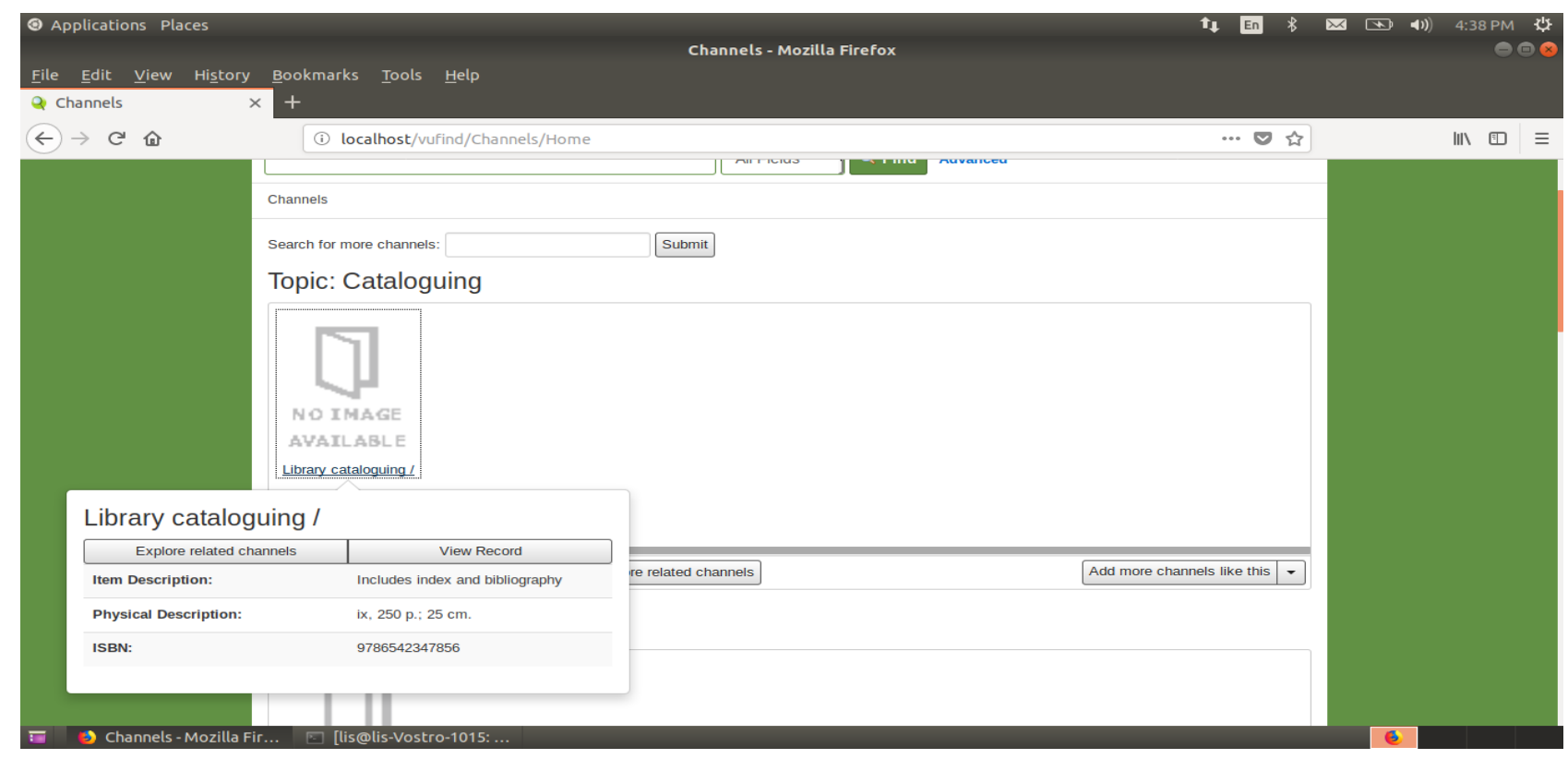

Figure -6 : Channel search interface in VuFind

\section{Browse Interface in VuFind}

Browsing interface is also provide by the VuFind discovery services. It can be display in different ways like tag, call number, author, topic, genre, region, and era. Now, agian tag can be devided in three ways by alphabetical, by popularity, and by recent. This is the beauty of VuFind discovery services. The Figure -7 is represents the browsing interface of VuFind. This interface is very important for each user of all the libraries.

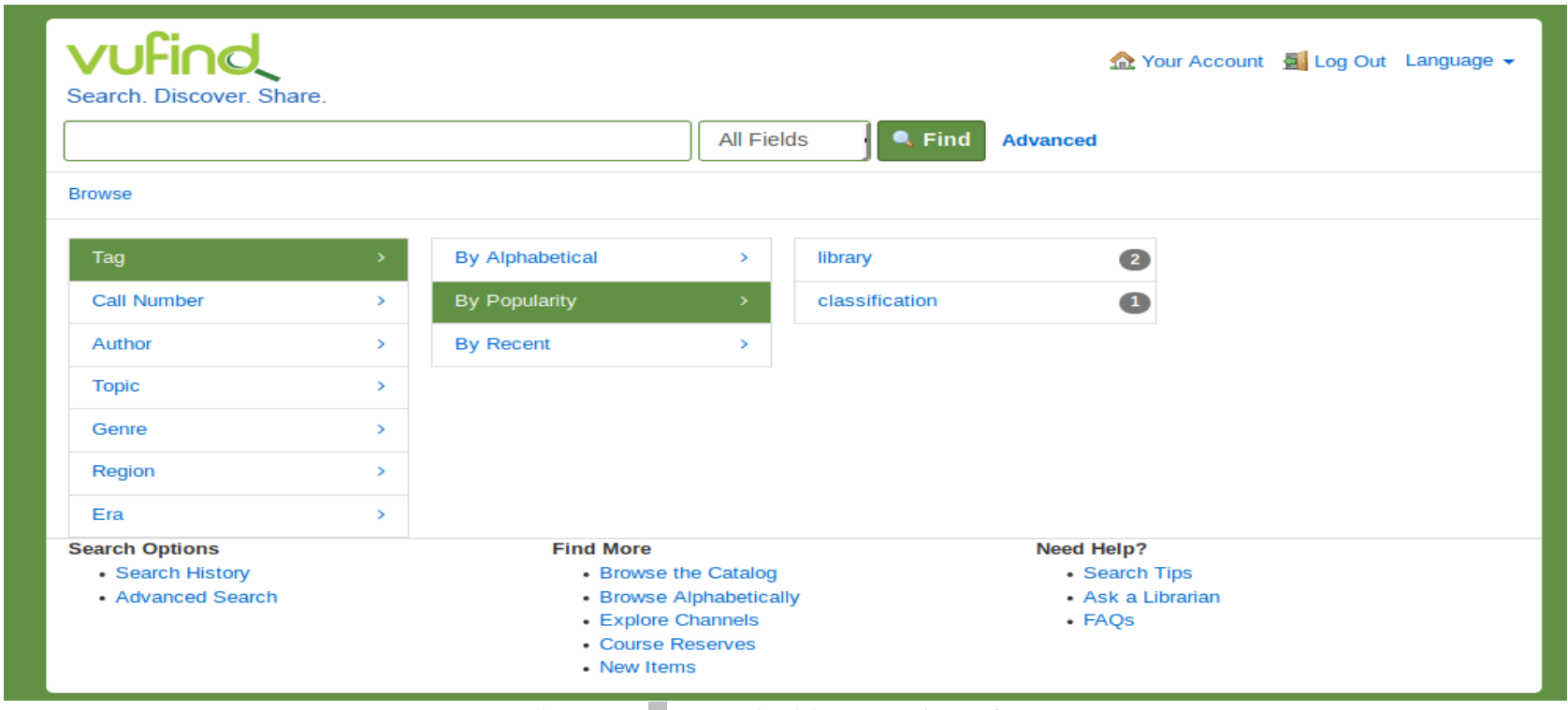

Figure -7 : VuFind browse interface 
DOI: https://dx.doi.org/10.26808/rs.ca.i8v1.09 International Journal of Computer Application (2250-1797) Issue 8 Volume 1, January- February 2018

\section{Conclusion}

The discovery service tools are effectively used now a days by general academicians and research scholars. But all these tools though available in the Internet yet the research scholars do not find exhaustive utility from these discovery tools so as to have numerous data required for his research work. But in this study one such discovery service tool has been used and exploited so as to make it effective to create a panoromic picture of relevant papers and their presentation from different mode point of view. The benefit of this study reveals many things to the research scholars and academicians. As such discovery interface provides various database in one interface through VuFind. Second benefit is that when search result appears in VuFind it manifest so many data where from a research scholar can find his particular information from various angles such as, one can obtain his required format of informative materials (i.e. ebook, book, theses, and etc.); one can also find his document through class number (i.e. T for Technology, $\mathrm{Q}$ for Science, $\mathrm{R}$ for Medicine, $\mathrm{H}$ for Social Science, B for Philosophy, Psychology, and Religion, and G for Geography and etc.). Thus, all these search facilities can be obtained through the application of VuFind discovery tool. In the Emerald database there are various types of documents such as database of books, database of journals, database of conference procedings and etc. In the Internet system one has to search the Emerald database by entering in the particular address. But in this VuFind discovery tool one can easily find not only the same Emerald database, but also the various other database available in the Internet campus. So this type of exhaustive database search in only possible with the help of this VuFind discovery tool. Reference management can equally be processed through the application of VuFind discovery tool such as American Psychological Association (APA), Modern Language Association (MLA), Chicago Mannual Style, and etc. can automatically cited as required by research scholar. Even all the various bibliographic data those are available in the Koha database can be visualized through the application of VuFind discovery tool which saves the time on the part of research scholars, which denies the various steps to be followed and the research scholar can see the bibliography of his relevant books very easily and efficiently. Apart from these one can find the number of copies available on a particular item and this is the very beauty of the VuFind discovery single window based interface. The channel search facility is available through this VuFind discovery tool where a research scholar can find the ISBN, view records and other relevant fields of his required document. Browse interface in VuFind is an excellent presentation to its protential users, where from an user can find his own document from tag, call number, topic, genre, region, era point of view. Even any one of these said searching aspects can be further classified for searching purpose, such as tag can be further classified as author, popularity, and recent point of view. Therefore, the application of VuFind discovery tool extends a greater opportunity in searching information, database, data of particular document, very systematically, exhaustively, and expedetiously which is the very needful demand of research scholar and his information seeking behavious is rightly fulfilled for having a greater aspects of information components and its features.

\section{References}

Condit Fagan, J., Mandernach, M., Nelson, C.S., Paulo, J.R. and Saunders, G. (2012) Usability Test Results for a Discovery Tool in an Academic Library. Information Technology \& Libraries, 31, 83-112. Retrieved from http://dx.doi.org/10.6017/ital.v31i1.1855 (Accessed on 26 ${ }^{\text {th }}$ December, 2017).

Gross, J. and Sheridan, L. (2011)Web Scale Discovery: The User Experience. New Library World, 112, 236-247. Retrieved from http://dx.doi.org/10.1108/03074801111136275 (Accessed on $24^{\text {th }}$ December, 2017). 
Henry, R. L. (2015). Moving from Theory to Practice: Incorporating Feminist Approaches into Search and Discovery Tool Development. The Journal of Academic Librarianship, 41(4), 514 - 516. http://doi.org/http://dx.doi.org/10.1016/j.acalib.2015.06.020

Hoeppner, A. (2012) .The Ins and Outs of Evaluating Web-Scale Discovery Services. Computers in Libraries, 32, 6-40.

Hoy, M.B. (2012) An Introduction to Web-Scale Discovery Systems. Medical Reference Services Quarterly, 31, 323-329. Retrieved from http://dx.doi.org/10.1080 /02763869. 2012. 698186 (Accessed on $24^{\text {th }}$ December, 2017).

Loughborough University (2013). Impact of library discovery technologies :a report for UKSG. Retrieved from www.uksg.org (Accessed on $24^{\text {th }}$ December, 2017).

Mandal, Sukumar (2017). Development of Domain Specific Cluster : An Integrated Framework for College Libraries under the University of Burdwan. Library Philosophy and Practice (Peer Review e-Journal).

Mandal, Sukumar \& Tripathi, Tridib (2016). E-Book Reader for the Learners in Ubuntu Operating System. pp. 42. World Science Congress, 6th International Science Congress, 23-25 December 2016, New Delhi.

Mandal, Sukumar (2016). Use of Search Indexing Tools in Library Automation: A Comparative Analysis. International Research Journal of Multidisciplinary Studies, 2 (6), 1-13.

Mandal, Sukumar (2016). Integrated library system for next generation automation: comparison of software, standards and services. International Journal of Multidisciplinary Research and Information, 2 (5), 337-342.

Mandal, Sukumar (2015). MultiTes: A Knowledge Organization Thesaurus Construction Tool for College Libraries under the University of Burdwan. International Research Journal of Interdisciplinary \& Multidisciplinary Studies (IRJIMS), 1 (8), 63-79.

Research information Network (2006).Researchers and discovery services:Behaviour, perceptions and needs. Retrieved from www.rin.ac.uk (Accessed on $29^{\text {th }}$ December, 2017).

Shi, Xi \& Levy, Sarah.(2015) . An Empirical Review of Library Discovery Tools. Journal of Service Science and Management, 8, 716-725.Retrieved from http://dx.doi.org/10.4236 /jssm.2015.85073 (Accessed on $26^{\text {th }}$ December, 2017).

Thompson, J., Obrig, K. and Abate, L. (2013) Web-Scale Discovery in an Academic Health Sciences Library. Medical Reference Services Quarterly, 32, 26-41. Retrieved from http://dx.doi.org /10.1080 /02763869.2013.749111(Accessed on $26^{\text {th }}$ December, 2017).

VuFind (2017). VuFind discovery tools. Retrieved from http://www.vufind.org/ (Accessed on 29th

December 2017) 